Discussion Paper No. 09-089

\title{
Open Source, ICT Infrastructure and Firm Performance
}

Daniel Cerquera and Bettina Müller

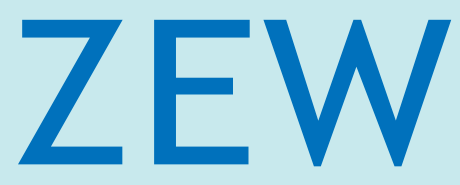

Zentrum für Europäische Wirtschaftsforschung $\mathrm{GmbH}$

Centre for European

Economic Research 


\title{
Discussion Paper No. 09-089 \\ Open Source, ICT Infrastructure and Firm Performance
}

\author{
Daniel Cerquera and Bettina Müller
}

Download this ZEW Discussion Paper from our ftp server:

ftp://ftp.zew.de/pub/zew-docs/dp/dp09089.pdf

Die Discussion Papers dienen einer möglichst schnellen Verbreitung von neueren Forschungsarbeiten des ZEW. Die Beiträge liegen in alleiniger Verantwortung der Autoren und stellen nicht notwendigerweise die Meinung des ZEW dar.

Discussion Papers are intended to make results of ZEW research promptly available to other economists in order to encourage discussion and suggestions for revisions. The authors are solely responsible for the contents which do not necessarily represent the opinion of the ZEW. 


\section{Non-technical summary}

The rapid diffusion of open source software (OSS), the significant investments observed in OSS projects, and the new inter-firm collaborative possibilities enabled by such OSS projects have generated a substantial literature on the economics of OSS development. However, this literature mainly focusses on the puzzling motivation for individual programmers and companies to produce OSS without systematically analyzing the economic impact of OSS on the economic performance of adopting firms. The question analyzed in this paper is whether the considerable costs incurred in the adoption and incorporation of OSS by the firms using OSS in their daily operations pay off.

In particular, this paper analyzes the impact of the adoption of three types of OSS (servers operating systems, PC operating systems and general software applications) on firms' labor productivity (sales per employee) and innovative behavior ( $R \& D$ intensities and value of introduced product and process innovations). In order to perform this analysis the paper exploits a unique representative sample of the German manufacturing and service sectors (ZEW ICT survey).

The results show that the adoption of open source operating systems for servers and general open source software applications has no impact on firm level labor productivity, while the adoption of open source operating systems for PCs impacts labor productivity negatively. This result suggests that the adoption of this type of OSS represents learning costs that affect the output per employee negatively, at least in the short run. Moreover, the results also show that the adoption of open source operating systems for PCs affects the value of process innovations (i.e. the percentage of cost reductions due to the introduction of previous process innovations) positively. This result suggests that the adoption of OSS helps firms to optimize their computationally intensive internal processes. This interpretation is supported by the observed positive correlation between open source operating systems for servers and PCs, and firms' R\&D intensities. 


\section{Das Wichtigste in Kürze}

Die rasche Verbreitung von Open Source Software (OSS), die umfangreichen Investitionen in OSS-Projekte und die Möglichkeiten zur Zusammenarbeit zwischen Firmen, die durch OSSProjekte eröffnet werden, haben in jüngster Zeit eine umfangreiche Literatur zur Ökonomie der Entwicklung von OSS hervorgebracht. Diese Literatur konzentriert sich hauptsächlich auf die Motivation von Individuen und Unternehmen, OSS bereit zu stellen. Der Einfluss von OSS auf die Performance von anwendenden Unternehmen wird dagegen nicht systematisch analysiert. In diesem Papier wird die Frage untersucht, ob sich die Kosten, die mit der Einführung und Verwendung von OSS verbunden sind, auszahlen.

Unter Verwednung eines repräsentativen Datensatzes für das verarbeitende Gewerbe und die Dienstleistungssektoren in Deutschland (ZEW IKT-Umfrage) wird in diesem Papier der Einfluss des Einsatzes von OSS auf die Unternehmensperformance empirisch untersucht. Es wird der Einfluss von drei Arten von OSS (Betriebssysteme für Server, Betriebssysteme für PCs und allgemeine OSS-Anwendungen) auf die Arbeitsproduktivität (Umsatz pro Beschäftigtem) und das Innovationsverhalten (F\&E-Intensitäten und Wert der eingeführten Produkt- und Prozessinnovationen) analysiert.

Die Ergebnisse zeigen, dass der Einsatz von OSS für Serverbetriebssysteme und allgemeine OSS-Anwendungen keinen Einfluss auf die Arbeitsproduktivität der Unternehmen hat. Der Einsatz von OSS für PC-Betriebssysteme hat dagegen einen negativen Einfluss auf die Arbeitsproduktivität. Dieses Ergebnis deutet darauf hin, dass der Einsatz von dieser Art von OSS mit Lernkosten verbunden sind, die den Output pro Beschäftigtem zumindest kurzfristig negativ beeinflussen. Die Ergebnisse zeigen weiterhin, dass der Einsatz von OSS für PCs den Wert von Prozessinnovationen (den Anteil von Kostenreduktionen aufgrund der Einführung von bereits eingeführten Prozessinnovationen) positiv beeinflusst. Dieses Ergebnis legt nahe, dass die Einführung von OSS den Unternehmen hilft, ihre rechenintensiven Prozesse zu optimieren. Diese Interpretation wird durch die positive Korrelation zwischen OSS für Serverbetriebssysteme und PCs und den F\&E-Intensitäten der Unternehmen unterstützt. 


\title{
Open Source, ICT Infrastructure and Firm Performance*
}

\author{
Daniel CERQUERA ${ }^{\dagger}$ \\ Bettina MÜLLER $\ddagger$ \\ ZEW Mannheim \\ Germany
}

December 27, 2009

\begin{abstract}
This paper empirically studies the impact of the adoption of open source software (OSS) on firms' labor productivity and innovative behavior. Using a representative sample of German firms, the results show that the adoption of OSS operating systems for servers and general OSS applications has no impact on firm level labor productivity, while the adoption of OSS operating systems for PCs impacts labor productivity negatively. This result points to the costs associated with the implementation of open source software. Moreover, the analysis shows that the adoption of OSS operating systems for PCs has a positive effect on the value of introduced process innovations, suggesting efficiency gains by adopting a tailored ICT infrastructure. These benefits might explain the positive correlation observed between OSS operating systems for servers and PCs, and firms' R\&D intensities.
\end{abstract}

Keywords: Open Source, Information and Communication Technologies, R\&D Incentives, Innovation, Firm Level Data.

JEL Classification: D21, L25, O32.

\footnotetext{
${ }^{*}$ We would like to thank Irene Bertschek for helpful comments and suggestions. All errors are ours.

${ }^{\dagger}$ cerquera@zew.de. Centre for European Economic Research (ZEW), Mannheim, Germany. Research Group Information and Communication Technologies. Corresponding author.

${ }^{\ddagger}$ bettina.mueller@zew.de. Centre for European Economic Research (ZEW), Mannheim, Germany. Research Group Information and Communication Technologies.
} 


\section{Introduction}

The rapid diffusion of open source software (OSS), the significant investments observed in OSS projects, and the new inter-firm collaborative possibilities enabled by such OSS projects have generated a substantial literature on the economics of OSS development. ${ }^{1}$ At the core of this literature is the attempt to explain the puzzling motivation for individual programmers to make their products publicly available for others for free. With this research objective in mind, the existing literature focusses on the organization of OSS development, competition between OSS and proprietary software, innovation and knowledge diffusion within OSS projects, among others. ${ }^{2}$

However, existing analyses have not considered systematically the economic impact of OSS on the economic performance of adopting firms. The question is: Do the considerable costs incurred in the adoption and incorporation of OSS by the firms using OSS in their daily operations pay off? Can the answer to this question explain why after a rapid process of diffusion, the market share of OSS solutions is still very low in comparison with proprietary or commercial software? Regarding computationally intensive processes at the firm level, is it reasonable to expect a wide adoption of OSS-based cloud computing in the future? This paper attempts to shed some light on these questions.

More specifically, this paper empirically analyzes the impact of the adoption of different types of open source software at the firm level on several measures of firm performance. The analysis is carried out for a representative sample of German manufacturing and service sectors. In particular, the analysis considers the impact of the adoption of three types of OSS (servers' operating systems, PCs' operating systems and general software applications) on firms' labor productivity (i.e. sales per employee) and innovative behavior (i.e. R\&D intensities and value of introduced product and process innovations).

There are three main reasons that highlight the relevance of the present analysis. First, although it is well known that the quality embedded in OSS solutions is higher than in their commercial counterparts, the implementation of OSS requires advanced programming knowledge and potentially high learning costs. Moreover, given the important variability

\footnotetext{
${ }^{1}$ See for example Lerner and Tirole (2002), Johnson (2002), Myatt and Wallace (2002), Bitzer and Schröder (2005), Bessen (2006), and Bitzer, Schrettl, and Schröder (2007).

${ }^{2}$ See for example Kogut and Metiu (2001), Franke and Shah (2003), Franke and Hippel (2003), von Krogh, Spaeth, and Lakhani (2003), Lerner, Phatak, and Tirole (2006), Xu, Christley, and Madey (2006), Dahlander and Magnusson (2005, 2006), Rossi and Bonaccorsi (2006), Bitzer (2004), Casadesus-Masanell and Ghemawat (2006), Bonaccorsi, Giannangeli, and Rossi (2006), and Economides and Katsamakas (2006a,b).
} 
observed in the profits of ICT intensive firms, it is reasonable to expect that for some firms, the adoption of OSS solutions represents a too costly alternative. However, whether the considerable costs incurred in the adoption and incorporation of OSS pay off in terms of economic performance remains an empirical question.

Second, OSS has been praised as a solution to overcome the market power of a few number of software producers (i.e. Microsoft). Indeed, given the $90 \%$ worldwide market share of Windows as an operating system for PCs, consumers might benefit from high-quality alternatives that provide additional competition in the market and more variety to final users. Accordingly, several economic policies are particularly oriented at encouraging the production, adoption and implementation of OSS solutions (e.g. European open source observatory). However, to the best of our knowledge, there is no systematic analysis using representative data sets in order to guide economic policy in this area.

Third, there is currently an extensive debate about the future of internet and cloud computing. In particular, the recently launched Google Chrome OS, an operating system based on an OSS architecture, attempts to play a leading role in the future. Google's idea is to provide a simple-to-use open source operating system, combining Linux with Chrome, Google's browser, in order to develop web-based applications only. This paper argues that one way to evaluate whether it is reasonable to expect that firms can benefit from OSS-based cloud computing or not, is to analyze how firms that have already adopted OSS have benefited in terms of their economic performance.

Some of the arguments presented in this paper have been highlighted in the theoretical literature. For example, Kuan (2001) argues that the quality of OSS will in general be higher. The reason is that a provider of closed software does not know the needs of the consumers. If he cannot divide the market by a separating contract (i.e. offering a high quality software with a high price and a low quality software with a low price) he is forced to offer a software of middle quality with a middle price to serve both individuals with a low and a high willingness to pay. In contrast, open source software can be enhanced by the effort of the users, who know their needs. In an open source context the first-best quality can be achieved, whereas closed software leads only to a second-best solution due to asymmetric information.

Johnson (2006) shows that the quality of closed source software is likely to be lower because the development of closed software in profit-oriented firms provides the programmers with an incentive not to search for bugs in the codes of their peers. The reason is that the number 
of bugs found in the code can be used as a signal for the ability of the programmer. If programmers are paid according to their ability they may collude not to check each others code in order to avoid adverse effects on their wages.

Further, Bessen (2006) states that OSS is a complement to closed source software. OSS will be used by firms who have complex and specialized needs that cannot be met by the standard software of closed software providers. In general, self-programming yields the first-best effort level for the development of software. Contracting over software programming is socially inefficient as each party gets only a fraction of the total surplus. This reduces the incentive to exert effort in order to improve the software. But self-programming requires that the end-user has the capabilities to programm software.

This paper estimates a production function and an innovation equation in order to study the impact of the adoption of different types of open source software on firm performance. The results show that the adoption of OSS operating systems for servers and general OSS applications has no impact on firm level labor productivity, while the adoption of OSS operating systems for PCs impacts labor productivity negatively. This result suggests that the adoption of this type of OSS represents learning costs that affect the output per employee negatively, at least in the short run. Moreover, the results also show that the adoption of open source operating systems for PCs affect the value of process innovations (i.e. the percentage of cost reductions due to the introduction of previous process innovations) positively. This result suggests that the adoption of OSS helps firms to optimize their computationally intensive internal processes. This interpretation is supported by the observed positive correlation between open source operating systems for servers and PCs, and firms' R\&D intensities.

The paper is organized as follows. In section 2 the data used are summarized and the empirical strategy is presented. In section 3 the results of the analysis are shown. Section 4 concludes.

\section{Empirical Analysis}

\section{$2.1 \quad$ Data}

The analysis is based on two waves of a business survey carried out by the Centre for European Economic Research (ZEW) corresponding to the years 2003 and 2006 (ZEW ICT Survey). The data set is a representative sample of the German manufacturing and service sectors, 
and contains detailed information on the economic characteristics, performance and ICT use for 4,400 firms in each wave. Table 1 provides some descriptive statistics about the firms' general performance, innovative behavior, as well as the observed ICT infrastructure. The information on firms' performance and innovative behavior corresponds to the year 2006, while the information regarding the observed ICT infrastructure corresponds to the year 2003 for the firms active in 2006 .

In general, the surveyed firms exhibit a great variability with respect to sales (in millions euros), number of employees, gross investments and labor productivity (i.e. ratio between sales and number of employees). In addition, the empirical distributions of these variables appear to be left skewed. In particular, the median level of sales of the surveyed firm corresponds to 5 million euros in 2006, whereas the average is 137.5 millions. This indicates the presence of few very large companies in the data. Analogously, the median size of the surveyed firms in terms of number of employees is 40 with an average of 295 for the same year. Gross investments show a similar pattern. In 2006, the median and average level of gross investments is 0.2 and 27.2 millions euros, respectively. The same also holds for the distribution of labor productivity where the median and the mean are 0.12 and 0.24 million euros per employee, respectively. The variability and the skewness of the distributions is in line with similar data sets on the firm level.

Table 1 also includes information on the innovative behavior of the surveyed firms. In particular, the average level of $R \& D$ intensity defined as $R \& D$ expenditures as a proportion of the reported sales in 2006 is 8.8. As expected, the empirical distribution of the $R \& D$ incentives is also left skewed where only the highest quartile evidenced a R\&D intensity higher than 10.0. In terms of the size of the $R \& D$ department defined as the proportion of employees that work in $\mathrm{R} \& \mathrm{D}$, the behavior is similar. The average $\mathrm{R} \& \mathrm{D}$ department employed 11.8 percent of the total firms' employees.

In addition, information on innovation outputs is also available. This includes dummy variables indicating whether the firm introduced product or process innovations during the periods 2001-2003 and 2004-2006, the percentage of sales reported in 2006 that are derived from the product innovations introduced during the period 2004-2006 (mean: 14.0, median: 1.0) and the percentage of cost reductions achieved in 2006 from the introduction of process innovations during the period 2004-2006 (mean: 5.9, median: 0.0).

Furthermore, Table 1 presents information regarding the use and intensity of ICT within firms for the year 2003. The intensity in the use of ICT is measured by the percentage 
of employees working mainly with a $\mathrm{PC}(\mathrm{PCW})$ and is nearly equally distributed around the different percentiles with an average of 47.5 percent. Moreover, the data also provide information about different ICT software applications, namely enterprise resource planning (ERP), supply chain management (SCM) and customer relationship management (CRM). The proportion of firms that adopted these applications in 2003 were $60.3,39.6$ and 50.4, respectively. Finally, 33.6 percent apply OSS in any form.

Table 2 shows how the use of OSS are related to different firm characteristics. Firms using open source software have a higher fraction of employees working with PCs, a higher R\&D intensity and a higher fraction of R\&D employees regardless of which type of OSS is considered. Additionally, firms using OSS appear to benefit more from innovations. In comparison with firms that do not use open source software they can generate roughly a 5 percentage points higher fraction of their sales with new products and roughly a 2 percentage points higher cost reduction in their total costs. With respect to labor productivity, firms using open source software for their server operating systems have higher, but firms using open source software for PC operating systems and software applications have lower labor productivity.

\subsection{Empirical Modeling}

As shown in Tables 1 and 2, the available data suggest that the adoption of OSS might affect firm performance in terms of productivity and innovative behavior. However, descriptive statistic do not provide enough evidence that supports the causality and/or robustness of such relationship. In order to find out how persistent the descriptive correlations are and to what extent they can be interpreted as causal effects, multivariate analyses are conducted in the following. The basic empirical relationship considered in the econometric analysis takes the following form:

$$
Y_{i, t}=f\left(O S_{i, t-1}, I C T_{i, t-1}, X_{i, t-1}\right)
$$

where $\mathrm{Y}$ is a measure of firm performance, OS corresponds to the adoption of open source, ICT accounts for the ICT infrastructure within the firm, and $\mathrm{X}$ is a vector of relevant covariates. The time indices $t$ and $t-1$ refer to 2006 and 2003, respectively. In analyzing the empirical relation presented in equation (1), the paper explicitly considers the following issues. First, given the expected benefits in firm performance attached to the adoption of OSS (and that 
motivates its introduction in the first place), it is reasonable to expect the analysis to be subject to endogeneity problems. In the next subsection the paper discusses the extent of these problems and the identification strategy.

Second, the available data allow the analysis to account for several types of OSS that were observed to be adopted by the sample firms. In particular, the econometric analysis considers three types of OSS: i) OSS operating system for servers; ii) OSS operating system for PCs; and iii) OSS applications. Each type has its own objective within the firm and this aspect is considered in the results obtained in the analysis. Third, the analysis benefits from a rich set of covariates available from the ICT survey. In particular, the econometric specifications control for the extent of the ICT infrastructure within the firm, as well as firm specific, sectoral and location variables. The importance of these covariates will become apparent when our identification strategy is made explicit.

Fourth, in order to measure performance, the analysis uses two main variables, labor productivity and innovative activity. Labor productivity is specified as follows:

$$
y_{i, t}=A+\alpha l_{i, t}+\beta k_{i, t}+\gamma O S_{i, t-1}+\delta I C T_{i, t-1}+\rho X_{i, t-1}+u_{i, t},
$$

where $y_{i, t}$ is labor productivity for firm $i$ at time $t$ measured as sales per employee in natural logarithm, $A$ corresponds to the firm level productivity not accounted for by the use of inputs, $l_{i, t}$ is the firm's number of employees (in logs.), $k_{i, t}$ is the firm's capital stock proxied using the firm's gross investments (in logs), $O S_{i, t-1}$ is the type of open source adopted by firm $i$, and $I C T_{i, t-1}$ corresponds to the firm's ICT infrastructure. In particular, $I C T_{i, t-1}$ can be vector-valued considering a wide set of ICT variables, and $X_{i, t}$ are relevant covariates available in the data set. The objective of the analysis is to estimate the parameter $\gamma$.

As an alternative measure of firm performance, the analysis also considers the innovative activity at the firm level. The analysis of the impact of open source adoption of firms' innovative behavior is not only interesting in itself, but permits to see more directly whether the impact of the adoption of open source on the firms' labor productivity is driven by its effect on innovative activities.

In order to study the impact of open source on innovation, the econometric analysis estimates the following relationship: 


$$
I_{i, t}=\beta_{0}+\gamma O S_{i, t-1}+\delta I C T_{i, t-1}+\rho X_{i, t-1}+u_{i, t}
$$

where $I_{i, t}$ corresponds to a measure of innovative activity and the remaining variables are similar to the specification presented in equation (2), although the set of covariates might change in order to account for a better fit of the innovation equation. In particular, the variables for $I_{i, t}$ are the inputs, as well as the outputs of the firms' innovative activity presented in Table 1 and 2. As before, $\gamma$ is the parameter of interest.

\subsection{Identification Strategy}

The objective of the paper is to consistently estimate the parameter $\gamma$. In particular, the main identification strategy with respect to the impact of the adoption of open source software on firms' performance is based on three main considerations. First, the analysis corresponds to a cross sectional analysis with $t=2006$ and $t-1=2003$ where, in consequence, the OSS variables exhibit a three year lag with respect to the performance variables considered. Thus, it is assumed that the impact of the adoption of OSS in 2003 is independent of unobserved factors of the firms' performance observed in 2006. Second, the introduction of detailed information of the ICT infrastructure of the firms in 2003, captured by the set of variables in $I C T_{i, t-1}$, isolates the remaining impact of the adoption of OSS on the relationship between the firms' ICT strategy and their performance. That is, given the rapid depreciation of ICT capital, the ICT infrastructure of the firms in 2003 is assumed to be orthogonal to the labor productivity and/or innovation activity observed in 2006. Third, an instrumental variable approach is performed for cases where the exogeneity of firms' inputs and/or additional covariates cannot be assumed.

In particular, to account for the potential endogeneity problem in the estimation of production functions due to the simultaneity between inputs and outputs, the analysis instruments the main inputs (i.e. labor and investments in 2006) using their lagged values observed for the year 2003. With respect to the innovation equation, the analysis includes in the vector of covariates $X_{t-1}$ information regarding previous innovative activities (i.e. introduction of product and process innovations during the period 2001-2003) in order to account for firm specific innovative capabilities that might be contemporaneous to the performance measures observed in 2006. 


\section{Results}

\subsection{Open Source and Productivity}

As explained above, the analysis estimates the production function presented in equation (2). In all the specifications industry, export activity and location dummies where included and exhibited the expected signs. Exporting firms are on average more productive than non-exporting firms and firms located in east Germany tend to be less productive than their western counterparts. Regarding OSS, the adoption of OSS operating systems for servers (OSSRV) and general OSS applications $(O S A P P)$ in 2003 did not evidence any impact on the firms' labor productivity in 2006. This result was obtained for a wide set of alternative specifications.

In particular, columns 1-3 in Table 3 show some estimates of the impact of the adoption of OSSRV on labor productivity. Column 1 presents the estimates of a benchmark OLS regression where the coefficient on the main inputs, labor and investments, exhibit the expected sign and magnitude. However, the coefficient for OSSRV is insignificant (coeff: -0.0196, std. error: 0.0535$)$. In this specification, the analysis controls for several variables that account for the ICT infrastructure of the firms in 2003. In order to control for the potential endogeneity of the main inputs of production, columns 2-3 follow an instrumental variables approach, where labor and investments are instrumented using 3-year lagged variables. The estimates of the main inputs are clearly improved but the coefficient on OSSRV (on both specifications) remains statistically insignificant. Columns 4-6 provides a similar summary of the analysis of the effect of $O S A P P$ on labor productivity with identical results.

This initial result is not surprising. Consider the case of OSSRV. It can be argued that the general management and maintenance of the server infrastructure inside a firm corresponds to ICT specialists. These specialists could either be part of the firm (i.e. ICT department) or not (i.e. ICT outsourcing) and do not tend to be directly related with the main operation of the firm. Their role is to guarantee the well functioning of the ICT infrastructure within the firm and does not affect the output per employee. In consequence, although the adoption of OSSRV might or might not reduce operating costs, the results suggest that it does not seem to be related with the core competencies of the firms. With this interpretation, there is no reason to expect a direct impact of $O S S R V$ on the firms' labor productivity.

The case of $O S A P P$ can be different in nature but it is still not surprising. OSAPP could 
include any possible OSS application (e.g. Mozilla Firefox) that complements the software used by a firm's employees. If these applications only represent an extra (possibly minor) tool, then it can be expected that they play no specific role in the main activities of the firm. Moreover, the fact that $O S A P P$ does not affect labor productivity can also be explained if most of the surveyed firms adopted some form of OSAPP, making no difference between adopters and non-adopters. However, even though the data are not specific about the extent of the adoption of $O S A P P$, the available information reveals that such $O S A P P$ were not a common tool in 2003. That is, only $19.8 \%$ of the surveyed firms reported the adoption of $O S A P P$. Therefore, the absence of an impact of $O S A P P$ on labor productivity suggests that they played a minor role in the main activities of the firm.

Interestingly, the adoption of open source operating systems for PCs $(O S P C)$ does impact labor productivity negatively. Table 4 shows the results of this analysis. As a benchmark, column 1 presents the estimates from an OLS regression. The coefficients on the main inputs, labor and investments, exhibit the expected sign and magnitude, and the adoption of OSPC is negatively related to labor productivity. Thus, the negative relationship already found in the descriptive statistics (Table 2) persists after controlling for additional factors. In particular, this result still holds after controlling for the firms' ICT infrastructure (i.e. ICT intensity and use of ICT applications). This finding suggests that the adoption of $O S P C$ corresponds to a major part of the ICT infrastructure of the firm. If it were just a minor fraction, the coefficient of $O S P C$ should become insignificant after the ICT infrastructure is controlled for.

Columns 2-6 follow an instrumental variables approach, similar to the one presented in Table 3. Column 2 presents a basic specification using the main inputs of production and a set of general control variables. As can be observed, $O S P C$ exhibits no statistically significant impact on labor productivity. Note, however, that the model estimated in column 2 does not control for firms' ICT infrastructure. Column 3 considers the role of the intensity of ICT use. Under this specification, $O S P C$ exerts a negative impact on labor productivity, as suggested by the OLS analysis presented in column 1 and the descriptive statistics. The coefficient of $O S P C$ is -0.1121 with a standard error of 0.0637 . Although this coefficient is only significant at the $10 \%$-level, it is robust to different specifications. In particular, the negative impact of $O S P C$ on labor productivity still holds when ICT applications are considered in the analysis, as is the case in column 4 where the coefficient of $O S P C$ is -0.1212 (std. error: 0.0628).

In terms of the magnitude of the coefficients, these results suggest that the marginal impact of the adoption of OSS in the form of PC operating system reduces labor productivity by 
12.1\%. We consider this magnitude to be a considerable amount. That is, and calculating the marginal effect of a log-linear model, the introduction of this form of OSS represents a reduction in sales per employee of approximately 15, 25 and 48 thousand euros for firms at the 50 th, 75 th and 90 th percentile of the labor productivity empirical distribution, respectively.

The results from columns 1-4 in Table 4 imply that the costs of successfully adapting OSS operating systems in the PCs within the firm significantly affect the output per employee. This is consistent with anecdotal evidence suggesting that for average employees (i.e. not ICT specialists) the implementation and use of $O S P C$ can be costly, as time has to be invested in learning to cope and take full advantage of the adoption of $O S P C$. In addition, note that the results might be underestimating the real impact of $O S P C$ because the firm's employees might require time in order to exploit the merits of the open source strategy.

In particular, given the costs associated with the implementation of $O S P C$, it is reasonable to expect that firms adopting $O S P C$ provide extra ICT-related qualification to their employees. The available data also permits to test the validity of this assumption. The corresponding results are presented in column 5. More specifically, the model estimated in column 5 includes a dummy variable that takes the value of 1 if the firms provided additional ICT qualification to its employees $(I C T Q)$ in 2003. The coefficient of $O S P C$ remains significant and close to the value reported in the previous specification, while the coefficient of the ICT extra qualification variable is insignificant.

This result supports the interpretation that the adoption of $O S P C$ requires time to provide productivity benefits to the firm. That is, if providing ICT extra qualification is enough to allow the firm's employees to reap the benefits of the adoption of $O S S$, then the coefficient on $I C T Q$ should be positive and the coefficient of $O S P C$ should become smaller or statistically equal to zero. However, this is not the case and the results are robust to different specifications. Note that the fact that the coefficient of $I C T Q$ is insignificant does not mean that such qualification is unproductive. It suggests that its benefits might be enjoyed in the future and the cross sectional approach presented in Table 4 is not able to capture its impact.

As an additional test, column 6 analyzes whether contracting external ICT specialists might reduce the magnitude of the negative impact of $O S P C$ on productivity. In particular, the econometric model considers the preferred specification of column 4 and includes information on whether the firm contracted external ICT consultants in 2003 and/or outsourced its ICT schooling in the same year. As in the case of column 5 , the coefficients of the variables on contracting external ICT specialists is insignificant and the coefficient of $O S P C$ maintains 
its magnitude and statistical significance.

The results presented in column 6 should be interpreted with caution. The reason is that, given the benefits of ICT consulting are reaped in the future, this variable can be subject to endogeneity problems. However, the fact that the impact of $O S P C$ on productivity remains robust to alternative specifications, provides some confidence in the results reported.

\subsection{Open Source and Innovation}

In this subsection, the analysis estimates the model presented in equation (3). Similar to the results obtained for the analysis of OSS and labor productivity, the only type of OSS that exhibited a significant impact on the firms' innovative activity was $O S P C$. In consequence, the analysis is focused on this type of OSS but the general results are available upon request.

Building on the results concerning the firms' labor productivity, if the objective of $O S P C$ is to reduce operating costs, then it can be expected that $O S P C$ affect the value of the process innovations introduced in the firm. That is, if $O S P C$ is used by a firms' employees, and those employees identify and develop new process innovations, then the adoption of $O S P C$ could be related with the value of such innovations. This relationship could be either positive if $O S P C$ contributes to the optimization of the firms' internal processes, or negative if such adoption is too costly (as suggested by the results on labor productivity).

In order to explore this relationship, Table 5 presents the results of the analysis of the impact of $O S P C$ on the value of introduced process innovations, defined as the percentage of cost reductions achieved in 2006 from the introduction of process innovations during the period 2004-2006. Given our identification strategy, the analysis follows an OLS approach. ${ }^{3}$

Column 1 presents the basic specification without considering the ICT infrastructure of the surveyed firms. In addition, in order to control for innovative experience, the analysis includes a dummy variable that takes the value of 1 if the firm introduced process innovations during the period 2001-2003. As expected, innovative experience is valuable to the innovative activities of the surveyed firms. Moreover, the coefficient of $O S P C$ is 0.0209 and significant at the $1 \%$-level. This result suggests that, on average, the percentage of cost reductions achieved in 2006 from the introduction of process innovations during the period 2004-2006

\footnotetext{
${ }^{3} \mathrm{~A}$ similar analysis was performed considering the impact of $O S P C$ on the probability of introducing product innovation and on the value of such innovations, but the impact was never significant. These results are available upon request.
} 
was 2.1 percentage points higher for firms that adopted $O S P C$ in 2003. This is a considerable impact given the mean of the empirical distribution of the value of such innovations $(5.9 \%)$.

Columns 2-3 introduce the role of the firm's ICT infrastructure, showing a similar magnitude for the coefficients for $O S P C$, although their significance was reduced to $5 \%$. These results suggest that even though the implementation of $O S P C$ might reduce sales in the short run (as shown by the results on labor productivity), it has an independent positive impact on the efficiency of the introduced process innovations. These results are consistent with the interpretation that firms use $O S P C$ to optimize their internal processes. Moreover, this positive impact of $O S P C$ on innovative output highlights the benefits of a tailored ICT infrastructure. As a result, and to exploit those benefits, it is reasonable to expect that the introduction of $O S P C$ might be related with the incentives to perform R\&D. In order to consider such implication, the conditional correlation between $O S P C$ and $\mathrm{R} \& \mathrm{D}$ incentives is presented in Table 6 .

The first three columns presented in Table 6 correspond to the analysis of the impact of OSS on the firms' R\&D intensities, defined as total expenditures as a percentage of sales. In particular, the results show that the adoption of OSS operating systems for servers and PCs $(O S S R V$ and $O S P C$ ) is positively correlated with the firms' R\&D incentives (Coeff: 0.091, std. error: 0.0145). This result also holds when the dependent variable considered is the size of the R\&D department, defined as the total number of R\&D employees as a proportion of total employees and presented in columns 4-6. In addition, perhaps not surprisingly, the introduction of general OS applications $(O S A P P)$ does not seem to influence the extent of $R \& D$ within firms. The magnitude and significance of the coefficients reported for the three types of OSS in Table 6 are robust to alternative specifications.

These results suggest that given the benefits associated with the adoption of OSS with respect to the efficiency of the introduced process innovations, the firms might evidence an extra incentive to invest in R\&D. It is important to note that the results presented in Table 6 only corresponds to conditional correlations and cannot be interpreted as a causal relationship.

\section{Conclusions}

This paper empirically studies the impact of the adoption of OSS on firm performance. The results show that the adoption of OSS operating systems for servers and general OSS appli- 
cations has no impact on firm level labor productivity, while the adoption of OSS operating systems for PCs impacts labor productivity negatively. This result implies that, indeed, the adoption of this type of OSS might represent learning costs that affect negatively the output per employee, at least in the short run. Moreover, the results also show that the adoption of OSS operating systems for PCs affects the value of process innovations (i.e. the percentage of cost reductions due to the introduction of previous process innovations) positively. This result suggests that the adoption of OSS might help firms to optimize their computationally intensive internal processes. This interpretation seems to be supported by the positive correlation observed between OSS operating systems for servers and PCs, and firms' R\&D intensities. 


\section{References}

Bessen, J. (2006). Open Source Software: Free Provision of Complex Public Goods. In J. Bitzer and P. Schröder (Eds.), The Economics of Open Source Software Development (pp. 57-82). Amsterdam: Elsevier.

Bitzer, J. (2004). Commercial Versus Open Source Software: The Role of Product Heterogeneity in Competition. Economic Systems, 28, 369-381.

Bitzer, J., Schrettl, W., and Schröder, P. (2007). Intrinsic Motivation in Open Source Software Development. Journal of Comparative Economics, 35, 160-169.

Bitzer, J., and Schröder, P. (2005). Bug-Fixing and Code-Writing: The Private Provision of Open Source Software. Information Economics and Policy, 17, 389-406.

Bonaccorsi, A., Giannangeli, S., and Rossi, C. (2006). Entry Strategies Under Competing Standards: Hybrid Business Models in the Open Source Software Industry. Management Science, 52(7), 1085-1089.

Casadesus-Masanell, R., and Ghemawat, P. (2006). Dynamic Mixed Duopoly: A Model Motivated by Linux vs. Windows. Management Science, 52(7), 1072-1084.

Dahlander, L., and Magnusson, M. (2005). Relationships between open source software companies and communities: Observations from nordic firms. Research Policy, 34, 481 $-493$.

Dahlander, L., and Magnusson, M. (2006). Business Models and Community Relationships of Open Source Software Firms. In J. Bitzer and P. Schröder (Eds.), The Economics of Open Source Software Development (pp. 111 -130). Amsterdam: Elsevier.

Economides, N., and Katsamakas, E. (2006a). Linux vs. Windows: A Comparison of Application and Platform Innovation Incentives for Open Source and Proprietary Software Platforms. In J. Bitzer and P. Schröder (Eds.), The Economics of Open Source Software Development (pp. 207 - 218). Amsterdam: Elsevier.

Economides, N., and Katsamakas, E. (2006b). Two-Sided Competition of Proprietary vs. Open Source Technology Platforms and the Implications for the Software Industry. Management Science, 52(7), 1057-1071.

Franke, N., and Hippel, E. von. (2003). Satisfying Heterogeneous User Needs via Innovation Toolkits: The Case of Apache Security Software. Research Policy, 32, 1199-1215.

Franke, N., and Shah, S. (2003). How Communities Support Innovative Activities: An Exploration of Assistance and Sharing Among End-Users. Research Policy, 32, 157178.

Johnson, J. (2002). Open Source Software: Private Provision of a Public Good. Journal of 
Economics and Management Strategy, 11(4), 637-662.

Johnson, J. (2006). Collaboration, Peer Review and Open Source Software. Information Economcis and Policy, 477-497.

Kogut, B., and Metiu, A. (2001). Open-Source Software Development and Distributed Innovation. Oxford Review of Economic Policy, 17(2), 248-264.

Kuan, J. (2001). Open Source Software as Consumer Integration into Production (Discussion Paper). Haas School of Business, University of California, Berkeley.

Lerner, J., Phatak, P., and Tirole, J. (2006). The Dynamics of Open-Source Contributors. American Economic Review, 96(2), 114-118.

Lerner, J., and Tirole, J. (2002). Some Simple Economics of Open Source. The Journal of Industrial Economics, 50(2), 197-234.

Myatt, D., and Wallace, C. (2002). Equilibrium Selection and Public Good Provision: the Development of Open-Source Software. Oxford Review of Economic Policy, 18(4), 446461.

Rossi, C., and Bonaccorsi, A. (2006). Intrinsic Motivations and Profit-Oriented Firms in Open Source Software: Do Firms Practice What They Preach? In J. Bitzer and P. Schröder (Eds.), The Economics of Open Source Software Development (pp. 83 - 110). Amsterdam: Elsevier.

von Krogh, G., Spaeth, S., and Lakhani, K. (2003). Community, joining, and specialization in open source software innovation: A case study. Research Policy, 32(7), 1217 - 1241. Xu, J., Christley, S., and Madey, G. (2006). Application of Social Network Analysis to the Study of Open Source Software. In J. Bitzer and P. Schröder (Eds.), The Economics of Open Source Software Development (pp. 247 -269). Amsterdam: Elsevier. 


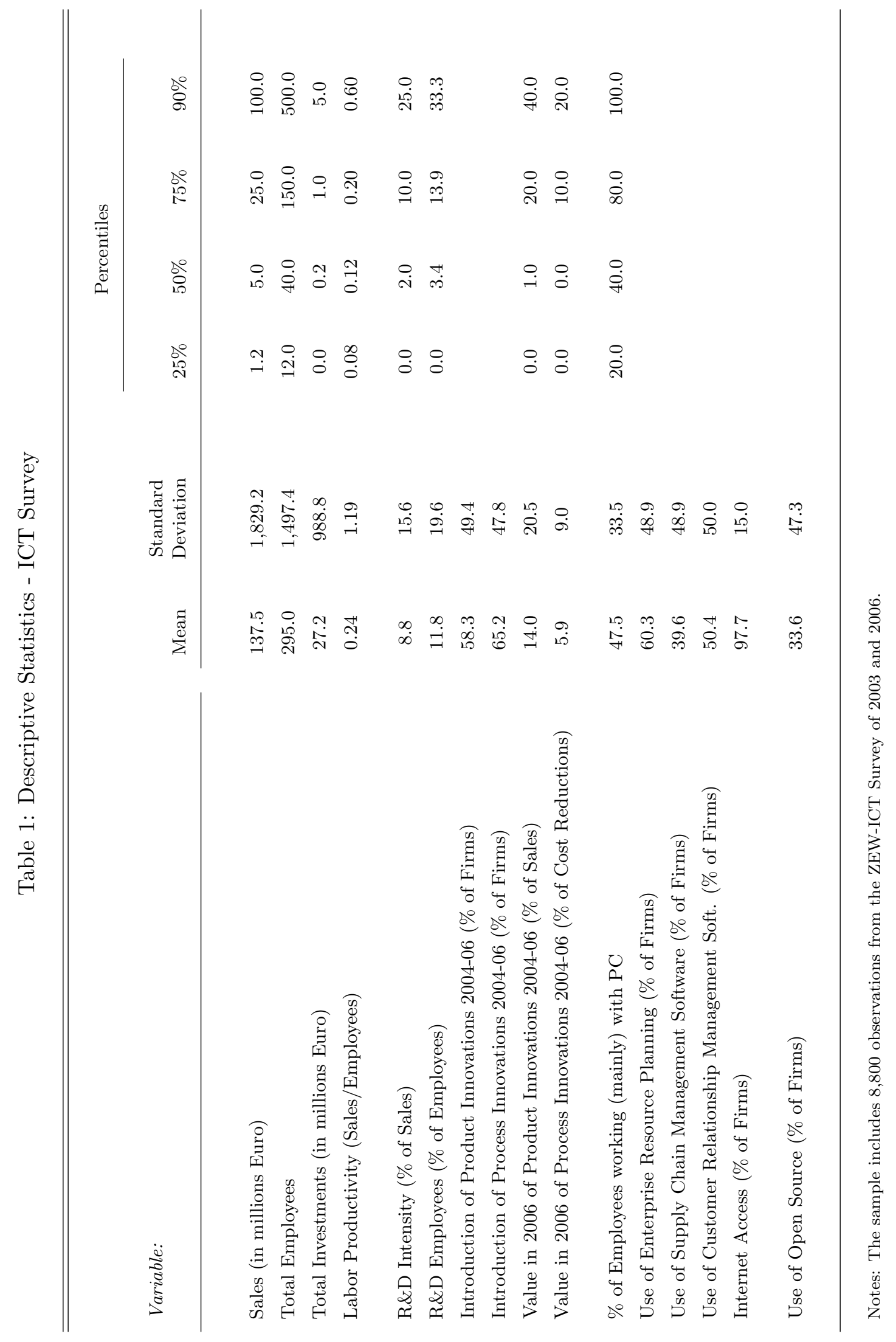




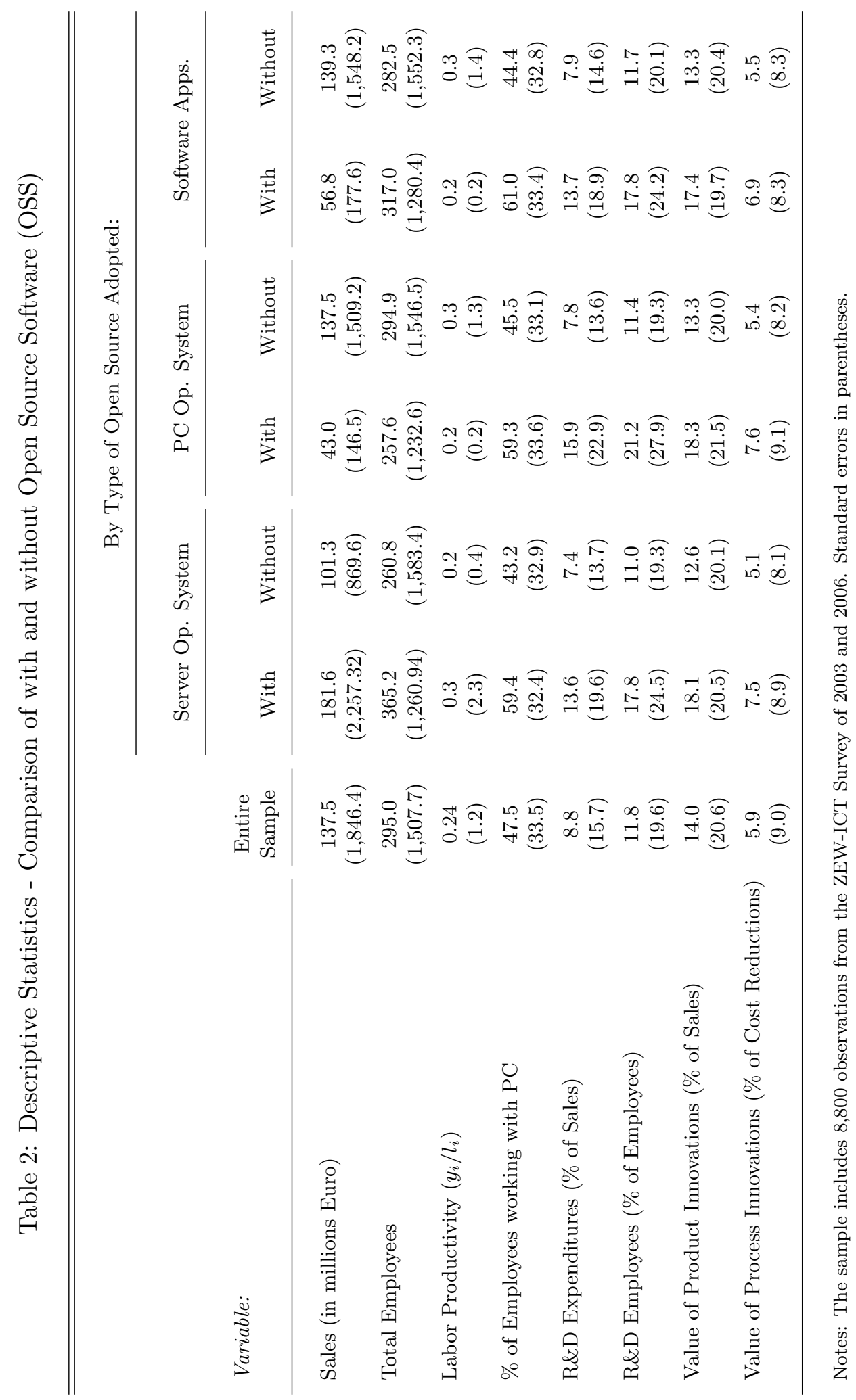


Table 3: Impact of the use of OSS (Servers and General Applications) on Labor Productivity

\begin{tabular}{|c|c|c|c|c|c|c|}
\hline \multirow{2}{*}{$\begin{array}{l}\text { Dependent Variable: } \\
\text { Labor Productivity } 2006 \text { (in Logs) }\end{array}$} & \multirow{2}{*}{$\begin{array}{l}\text { OLS } \\
(1)\end{array}$} & \multicolumn{2}{|c|}{ IV } & \multirow{2}{*}{$\begin{array}{l}\text { OLS } \\
(4)\end{array}$} & \multicolumn{2}{|c|}{ IV } \\
\hline & & $(2)$ & $(3)$ & & $(5)$ & $(6)$ \\
\hline Labor 2006 (in Logs) & $\begin{array}{c}-0.1691^{* * *} \\
(0.0325)\end{array}$ & $\begin{array}{c}-0.2951^{* * *} \\
(0.0488)\end{array}$ & $\begin{array}{c}-0.2759 * * * \\
(0.0464)\end{array}$ & $\begin{array}{c}-0.1692^{* * *} \\
(0.0322)\end{array}$ & $\begin{array}{c}-0.2953^{* * *} \\
(0.0487)\end{array}$ & $\begin{array}{c}-0.2772^{* * * *} \\
(0.0462)\end{array}$ \\
\hline Investments 2006 (in Logs) & $\begin{array}{c}0.1606^{* * *} \\
(0.0297)\end{array}$ & $\begin{array}{c}0.3298^{* * *} \\
(0.0460)\end{array}$ & $\begin{array}{c}0.3044^{* * *} \\
(0.0437)\end{array}$ & $\begin{array}{c}0.1610^{* * *} \\
(0.0296)\end{array}$ & $\begin{array}{c}0.3288^{* * *} \\
(0.0459)\end{array}$ & $\begin{array}{c}0.3030^{* * *} \\
(0.0436)\end{array}$ \\
\hline OS Servers' Op. Sys. (OSSRV) & $\begin{array}{l}-0.0196 \\
(0.0535)\end{array}$ & $\begin{array}{l}-0.0293 \\
(0.0561)\end{array}$ & $\begin{array}{l}-0.0885 \\
(0.0557)\end{array}$ & & & \\
\hline OS Applications (OSAPP) & & & & $\begin{array}{l}-0.0689 \\
(0.0545)\end{array}$ & $\begin{array}{l}-0.0002 \\
(0.0592)\end{array}$ & $\begin{array}{l}-0.0722 \\
(0.0588)\end{array}$ \\
\hline$\%$ of Employees with PC $(P C W)$ & $\begin{array}{c}0.5047^{* * *} \\
(0.0955)\end{array}$ & & $\begin{array}{c}0.5572^{* * *} \\
(0.1039)\end{array}$ & $\begin{array}{c}0.5114^{* * *} \\
(0.0952)\end{array}$ & & $\begin{array}{c}0.5549^{* * *} \\
(0.1045)\end{array}$ \\
\hline Enterprise Res. Planning $(E R P)$ & $\begin{array}{c}0.1129 * * \\
(0.0558)\end{array}$ & & $\begin{array}{c}0.0652 \\
(0.0623)\end{array}$ & $\begin{array}{c}0.1157^{* *} \\
(0.0559)\end{array}$ & & $\begin{array}{c}0.0685 \\
(0.0621)\end{array}$ \\
\hline Supply Chain Management $(S C M)$ & $\begin{array}{c}0.0551 \\
(0.0563)\end{array}$ & & $\begin{array}{c}0.0072 \\
(0.0592)\end{array}$ & $\begin{array}{c}0.0526 \\
(0.0563)\end{array}$ & & $\begin{array}{c}0.0059 \\
(0.0592)\end{array}$ \\
\hline Customer Rel. Management ( $C R M)$ & $\begin{array}{l}0.0446 \\
(0.0525)\end{array}$ & & $\begin{array}{c}0.1078 \\
(0.0536)\end{array}$ & $\begin{array}{c}0.0462 \\
(0.0524)\end{array}$ & & $\begin{array}{l}0.1031^{*} \\
(0.0532)\end{array}$ \\
\hline Export Activity & $\begin{array}{c}0.1628^{* * *} \\
(0.0577)\end{array}$ & $\begin{array}{c}0.2082^{* * *} \\
(0.0598)\end{array}$ & $\begin{array}{c}0.1452^{* *} \\
(0.0588)\end{array}$ & $\begin{array}{c}0.1625^{* * *} \\
(0.0572)\end{array}$ & $\begin{array}{c}0.2051^{* * *} \\
(0.0593)\end{array}$ & $\begin{array}{c}0.1403^{* *} \\
(0.0584)\end{array}$ \\
\hline East Germany & $\begin{array}{c}-0.2297^{* * *} \\
(0.0550)\end{array}$ & $\begin{array}{c}-0.1334^{* *} \\
(0.0597)\end{array}$ & $\begin{array}{c}-0.1279 * * \\
(0.0582)\end{array}$ & $\begin{array}{c}-0.2315^{* * *} \\
(0.0550)\end{array}$ & $\begin{array}{c}-0.1351^{* *} \\
(0.0596)\end{array}$ & $\begin{array}{c}-0.1343^{* *} \\
(0.0580)\end{array}$ \\
\hline Constant & $\begin{array}{c}-1.4355^{* * *} \\
(0.1876)\end{array}$ & $\begin{array}{c}-0.5329^{* *} \\
(0.2507)\end{array}$ & $\begin{array}{c}-0.8347^{* * *} \\
(0.2474)\end{array}$ & $\begin{array}{c}-1.4337^{* * *} \\
(0.1871)\end{array}$ & $\begin{array}{c}-0.5378^{* *} \\
(0.2506)\end{array}$ & $\begin{array}{c}-0.8365^{* * * *} \\
(0.2469)\end{array}$ \\
\hline Number of Observations & 1029 & 847 & 845 & 1029 & 847 & 845 \\
\hline F-statistic & 13.62 & & & 13.76 & & \\
\hline Wald- $\chi^{2}$-statistic & & 213.99 & 271.99 & & 214.34 & 274.02 \\
\hline$R^{2}$ & 0.2594 & 0.2057 & 0.2617 & 0.2603 & 0.2063 & 0.2619 \\
\hline
\end{tabular}


Table 4: Impact of the use of OSS (PC Operating Systems) on Labor Productivity

Dependent Variable:

OLS

Instrumental Variables

Labor Productivity 2006 (in Logs)

(1)

(2)

(3)

(4)

(5)

(6)

\begin{tabular}{|c|c|c|c|c|c|c|}
\hline Labor 2006 (in Logs) & $\begin{array}{c}-0.1718^{* * *} \\
(0.0320)\end{array}$ & $\begin{array}{c}-0.2974^{* * *} \\
(0.0487)\end{array}$ & $\begin{array}{c}-0.2710^{* * *} \\
(0.0465)\end{array}$ & $\begin{array}{c}-0.2805^{* * *} \\
(0.0461)\end{array}$ & $\begin{array}{c}-0.2799 * * * \\
(0.0480)\end{array}$ & $\begin{array}{c}-0.2975^{* * *} \\
(0.0448)\end{array}$ \\
\hline Investments 2006 (in Logs) & $\begin{array}{c}0.1622^{* * *} \\
(0.0295)\end{array}$ & $\begin{array}{c}0.3311^{* * *} \\
(0.0460)\end{array}$ & $\begin{array}{c}0.3136^{* * *} \\
(0.0434)\end{array}$ & $\begin{array}{c}0.3055^{* * *} \\
(0.0436)\end{array}$ & $\begin{array}{c}0.3061^{* * *} \\
(0.0451)\end{array}$ & $\begin{array}{c}0.3217^{* * *} \\
(0.0433)\end{array}$ \\
\hline OS PCs' Op. Sys. $(O S P C)$ & $\begin{array}{c}-0.1109^{*} \\
(0.0621)\end{array}$ & $\begin{array}{l}-0.0704 \\
(0.0640)\end{array}$ & $\begin{array}{c}-0.1121^{*} \\
(0.0637)\end{array}$ & $\begin{array}{c}-0.1212^{*} \\
(0.0628)\end{array}$ & $\begin{array}{c}-0.1259^{* *} \\
(0.0632)\end{array}$ & $\begin{array}{c}-0.1290^{* *} \\
(0.0631)\end{array}$ \\
\hline$\%$ of Employees with PC $(P C W)$ & $\begin{array}{c}0.5087^{* * *} \\
(0.0947)\end{array}$ & & $\begin{array}{c}0.6157^{* * *} \\
(0.1042)\end{array}$ & $\begin{array}{c}0.5550^{* * *} \\
(0.1030)\end{array}$ & $\begin{array}{c}0.5559^{* * *} \\
(0.1005)\end{array}$ & $\begin{array}{c}0.5445^{* * *} \\
(0.1031)\end{array}$ \\
\hline Enterprise Res. Planning (ERP) & $\begin{array}{c}0.1176^{* *} \\
(0.0558)\end{array}$ & & & $\begin{array}{c}0.0701 \\
(0.0621)\end{array}$ & $\begin{array}{c}0.0648 \\
(0.0640)\end{array}$ & $\begin{array}{c}0.0782 \\
(0.0645)\end{array}$ \\
\hline Supply Chain Management $(S C M)$ & $\begin{array}{c}0.0541 \\
(0.0561)\end{array}$ & & & $\begin{array}{c}0.0079 \\
(0.0588)\end{array}$ & $\begin{array}{c}0.0129 \\
(0.0594)\end{array}$ & $\begin{array}{c}-0.0038 \\
(0.0593)\end{array}$ \\
\hline Customer Rel. Management ( $C R M)$ & $\begin{array}{c}0.0470 \\
(0.0522)\end{array}$ & & & $\begin{array}{l}0.1038^{*} \\
(0.0532)\end{array}$ & $\begin{array}{l}0.0980^{*} \\
(0.0543)\end{array}$ & $\begin{array}{l}0.0934^{*} \\
(0.0538)\end{array}$ \\
\hline \multicolumn{3}{|l|}{ Extra ICT-related Qualification $(I C T Q)$} & & & $\begin{array}{c}0.0666 \\
(0.1777)\end{array}$ & \\
\hline ICT Consulting & & & & & & $\begin{array}{l}-0.0342 \\
(0.0534)\end{array}$ \\
\hline Outsourcing of ICT Schooling & & & & & & $\begin{array}{c}0.0542 \\
(0.1017)\end{array}$ \\
\hline Export Activity & $\begin{array}{c}0.1691^{* * *} \\
(0.0579)\end{array}$ & $\begin{array}{c}0.2107^{* * *} \\
(0.0595)\end{array}$ & $\begin{array}{c}0.1710^{* * *} \\
(0.0583)\end{array}$ & $\begin{array}{c}0.1454^{* *} \\
(0.0586)\end{array}$ & $\begin{array}{c}0.1486^{* *} \\
(0.0588)\end{array}$ & $\begin{array}{c}0.1393^{* *} \\
(0.0590)\end{array}$ \\
\hline East Germany & $\begin{array}{c}-0.2269^{* * *} \\
(0.0546)\end{array}$ & $\begin{array}{c}-0.1325^{* *} \\
(0.0596)\end{array}$ & $\begin{array}{c}-0.1191^{* *} \\
(0.0583)\end{array}$ & $\begin{array}{c}-0.1284^{* *} \\
(0.0580)\end{array}$ & $\begin{array}{c}-0.1236^{* *} \\
(0.0587)\end{array}$ & $\begin{array}{c}-0.1233^{* *} \\
(0.0581)\end{array}$ \\
\hline Constant & $\begin{array}{c}-1.4180^{* * *} \\
(0.1853)\end{array}$ & $\begin{array}{c}-0.5189^{* *} \\
(0.2516)\end{array}$ & $\begin{array}{c}-0.7984^{* * *} \\
(0.2482)\end{array}$ & $\begin{array}{c}-0.8155^{* * *} \\
(0.2468)\end{array}$ & $\begin{array}{c}-0.8082^{* * *} \\
(0.2570)\end{array}$ & $\begin{array}{c}-0.7379^{* * *} \\
(0.2647)\end{array}$ \\
\hline Number of Observations & 1029 & 847 & 845 & 845 & 838 & 833 \\
\hline F-statistic & 13.78 & & & & & \\
\hline Wald- $\chi^{2}$-statistic & & 214.39 & 267.79 & 274.58 & 272.46 & 284.77 \\
\hline$R^{2}$ & 0.2614 & 0.2057 & 0.2502 & 0.2623 & 0.2622 & 0.2666 \\
\hline
\end{tabular}


Table 5: Impact of OSS on the Value of Introduced Process Innovations

Dependent Variable:

Value of Introduced

Process Innovations 2006
(1)
Ordinary Least Squares

\begin{tabular}{|c|c|c|c|c|c|c|}
\hline OS PCs' Op. Sys. $(O S P C)$ & $\begin{array}{c}0.0209^{* * *} \\
(0.0079)\end{array}$ & $\begin{array}{c}0.0198^{* *} \\
(0.0078)\end{array}$ & $\begin{array}{c}0.0180^{* *} \\
(0.0077)\end{array}$ & $\begin{array}{c}-0.0083 \\
(0.0089)\end{array}$ & $\begin{array}{c}-0.0082 \\
(0.0089)\end{array}$ & $\begin{array}{c}-0.0089 \\
(0.0090)\end{array}$ \\
\hline Labor 2006 (in Logs) & $\begin{array}{c}-0.0026 \\
(0.0025)\end{array}$ & $\begin{array}{l}-0.0018 \\
(0.0025)\end{array}$ & $\begin{array}{c}-0.0042 \\
(0.0026)\end{array}$ & $\begin{array}{l}-0.0036 \\
(0.0026)\end{array}$ & $\begin{array}{c}-0.0037 \\
(0.0026)\end{array}$ & $\begin{array}{l}-0.0035 \\
(0.0026)\end{array}$ \\
\hline Investments 2006 (in Logs) & $\begin{array}{c}0.0034^{*} \\
(0.0019)\end{array}$ & $\begin{array}{c}0.0032^{*} \\
(0.0019)\end{array}$ & $\begin{array}{c}0.0025 \\
(0.0018)\end{array}$ & $\begin{array}{c}0.0024 \\
(0.0018)\end{array}$ & $\begin{array}{c}0.0025 \\
(0.0018)\end{array}$ & $\begin{array}{c}0.0025 \\
(0.0019)\end{array}$ \\
\hline Process Innovations 2001-2003 & $\begin{array}{c}0.0226^{* * *} \\
(0.0055)\end{array}$ & $\begin{array}{c}0.0213^{* * *} \\
(0.0056)\end{array}$ & $\begin{array}{c}0.0198 * * * \\
(0.0056)\end{array}$ & $\begin{array}{c}0.0196^{* * *} \\
(0.0055)\end{array}$ & $\begin{array}{c}0.0197^{* * *} \\
(0.0056)\end{array}$ & $\begin{array}{c}0.0182^{* * *} \\
(0.0057)\end{array}$ \\
\hline$\%$ of Employees with PC $(P C W)$ & & $\begin{array}{c}0.0254^{* *} \\
(0.0100)\end{array}$ & $\begin{array}{l}0.0194^{*} \\
(0.0100)\end{array}$ & $\begin{array}{c}0.0192^{*} \\
(0.0099)\end{array}$ & $\begin{array}{c}0.0199 * * \\
(0.0099)\end{array}$ & $\begin{array}{l}0.0174^{*} \\
(0.0104)\end{array}$ \\
\hline Enterprise Res. Planning ( $E R P)$ & & & $\begin{array}{c}0.0130 * * \\
(0.0064)\end{array}$ & $\begin{array}{c}0.0134^{* *} \\
(0.0064)\end{array}$ & $\begin{array}{c}0.0132^{* *} \\
(0.0064)\end{array}$ & $\begin{array}{c}0.0119^{*} \\
(0.0066)\end{array}$ \\
\hline Supply Chain Management $(S C M)$ & & & $\begin{array}{c}0.0124^{*} \\
(0.0065)\end{array}$ & $\begin{array}{c}0.0127^{* *} \\
(0.0064)\end{array}$ & $\begin{array}{l}0.0120^{*} \\
(0.0064)\end{array}$ & $\begin{array}{l}0.0127^{*} \\
(0.0065)\end{array}$ \\
\hline Customer Rel. Management (CRM) & & & $\begin{array}{c}0.0045 \\
(0.0057)\end{array}$ & $\begin{array}{l}-0.0030 \\
(0.0061)\end{array}$ & $\begin{array}{l}-0.0040 \\
(0.0061)\end{array}$ & $\begin{array}{l}-0.0036 \\
(0.0062)\end{array}$ \\
\hline$O S P C \times C R M$ & & & & $\begin{array}{c}0.0459^{* * *} \\
(0.0141)\end{array}$ & $\begin{array}{c}0.0439^{* * *} \\
(0.0139)\end{array}$ & $\begin{array}{c}0.0434^{* * *} \\
(0.0141)\end{array}$ \\
\hline $\mathrm{B} 2 \mathrm{C}$ & & & & & $\begin{array}{c}0.0132^{* *} \\
(0.0065)\end{array}$ & $\begin{array}{l}0.0110^{*} \\
(0.0066)\end{array}$ \\
\hline Extra IT-related Qualification $(I C T Q$ & & & & & & $\begin{array}{c}0.0216 \\
(0.0143)\end{array}$ \\
\hline ICT Consulting & & & & & & $\begin{array}{l}-0.0016 \\
(0.0057)\end{array}$ \\
\hline Outsourcing of ICT Schooling & & & & & & $\begin{array}{c}0.0001 \\
(0.0078)\end{array}$ \\
\hline Export Activity & $\begin{array}{l}-0.0061 \\
(0.0058)\end{array}$ & $\begin{array}{l}-0.0084 \\
(0.0059)\end{array}$ & $\begin{array}{c}-0.0124^{* *} \\
(0.0060)\end{array}$ & $\begin{array}{c}-0.0126^{* *} \\
(0.0060)\end{array}$ & $\begin{array}{c}-0.0121^{* *} \\
(0.0060)\end{array}$ & $\begin{array}{c}-0.0115^{*} \\
(0.0061)\end{array}$ \\
\hline East Germany & $\begin{array}{c}-0.0091^{*} \\
(0.0055)\end{array}$ & $\begin{array}{c}-0.0090^{*} \\
(0.0054)\end{array}$ & $\begin{array}{c}-0.0089^{*} \\
(0.0054)\end{array}$ & $\begin{array}{l}-0.0080 \\
(0.0053)\end{array}$ & $\begin{array}{l}-0.0079 \\
(0.0053)\end{array}$ & $\begin{array}{l}-0.0079 \\
(0.0054)\end{array}$ \\
\hline Constant & $\begin{array}{c}0.0511^{* * *} \\
(0.0148)\end{array}$ & $\begin{array}{c}0.0424^{* * *} \\
(0.0150)\end{array}$ & $\begin{array}{c}0.0427^{* * *} \\
(0.0149)\end{array}$ & $\begin{array}{c}0.0428^{* * *} \\
(0.0149)\end{array}$ & $\begin{array}{c}0.0404^{* * *} \\
(0.0150)\end{array}$ & $\begin{array}{c}0.0406^{* *} \\
(0.0163)\end{array}$ \\
\hline Number of Observations & 1035 & 1033 & 1033 & 1033 & 1032 & 1009 \\
\hline F-statistic & 3.34 & 3.33 & 3.83 & 3.79 & 3.82 & 3.52 \\
\hline$R^{2}$ & 0.0526 & 0.0600 & 0.0722 & 0.0821 & 0.0862 & 0.0905 \\
\hline
\end{tabular}

Robust standard errors in parenthesis. Industry dummies included.

$* * *, * *, *$ depict significance at the $1 \%, 5 \%$ and $10 \%$ level respectively.

(6) 
Table 6: Impact of Open Source Software on R\&D Intensities

\begin{tabular}{|c|c|c|c|c|c|c|}
\hline \multirow{3}{*}{ Dependent Variable: } & \multicolumn{6}{|c|}{ Ordinary Least Squares } \\
\hline & \multicolumn{3}{|c|}{$\begin{array}{c}\text { RGD Expenditures } \\
\text { (\% of Sales) }\end{array}$} & \multicolumn{3}{|c|}{$\begin{array}{l}\text { RED Employees } \\
\text { (\% of Employees) }\end{array}$} \\
\hline & $(1)$ & $(2)$ & $(3)$ & $(4)$ & $(5)$ & $(6)$ \\
\hline OS Servers' Op. Sys. (OSSRV) & $\begin{array}{r}0.0291^{* *} \\
(0.0145)\end{array}$ & & & $\begin{array}{l}0.0241^{*} \\
(0.0138)\end{array}$ & & \\
\hline OS PCs' Op. Sys. $(O S P C)$ & & $\begin{array}{l}0.0304^{*} \\
(0.0174)\end{array}$ & & & $\begin{array}{l}0.0313^{*} \\
(0.0183)\end{array}$ & \\
\hline OS Applications (OSAPP) & & & $\begin{array}{c}0.0242 \\
(0.0153)\end{array}$ & & & $\begin{array}{c}0.0133 \\
(0.0151)\end{array}$ \\
\hline Labor 2006 (in Logs) & $\begin{array}{l}-0.0008 \\
(0.0049)\end{array}$ & $\begin{array}{l}-0.0002 \\
(0.0049)\end{array}$ & $\begin{array}{l}-0.0007 \\
(0.0049)\end{array}$ & $\begin{array}{c}-0.0302^{* * *} \\
(0.0061)\end{array}$ & $\begin{array}{c}-0.0295 * * * \\
(0.0061)\end{array}$ & $\begin{array}{c}-0.0300^{* * *} \\
(0.0061)\end{array}$ \\
\hline Investments 2006 (in Logs) & $\begin{array}{c}0.0006 \\
(0.0033)\end{array}$ & $\begin{array}{c}0.0010 \\
(0.0032)\end{array}$ & $\begin{array}{c}0.0012 \\
(0.0032)\end{array}$ & $\begin{array}{c}0.0000 \\
(0.0042)\end{array}$ & $\begin{array}{c}0.0001 \\
(0.0042)\end{array}$ & $\begin{array}{c}0.0004 \\
(0.0042)\end{array}$ \\
\hline$\%$ of Employees with PC $(P C W)$ & $\begin{array}{c}0.0295 \\
(0.0201)\end{array}$ & $\begin{array}{c}0.0335 \\
(0.0209)\end{array}$ & $\begin{array}{c}0.0321 \\
(0.0209)\end{array}$ & $\begin{array}{c}0.0568^{* * * *} \\
(0.0224)\end{array}$ & $\begin{array}{l}0.0589^{*} \\
(0.0227)\end{array}$ & $\begin{array}{l}0.0589^{*} \\
(0.0228)\end{array}$ \\
\hline Product Innovations 2001-2003 & $\begin{array}{c}0.0226^{* *} \\
(0.0100)\end{array}$ & $\begin{array}{c}0.0236^{* *} \\
(0.0100)\end{array}$ & $\begin{array}{c}0.0236^{* *} \\
(0.0101)\end{array}$ & $\begin{array}{c}0.0579^{* * *} \\
(0.0122)\end{array}$ & $\begin{array}{c}0.0580^{* * *} \\
(0.0123)\end{array}$ & $\begin{array}{c}0.0587^{* * *} \\
(0.0123)\end{array}$ \\
\hline Enterprise Res. Planning (ERP) & $\begin{array}{c}0.0057 \\
(0.0117)\end{array}$ & $\begin{array}{c}0.0041 \\
(0.0117)\end{array}$ & $\begin{array}{c}0.0050 \\
(0.0117)\end{array}$ & $\begin{array}{l}-0.0075 \\
(0.0140)\end{array}$ & $\begin{array}{r}-0.0087^{*} \\
(0.0140)\end{array}$ & $\begin{array}{l}-0.0081 \\
(0.0140)\end{array}$ \\
\hline Supply Chain Management $(S C M)$ & $\begin{array}{c}0.0319^{* * *} \\
(0.0128)\end{array}$ & $\begin{array}{c}0.0311^{* *} \\
(0.0128)\end{array}$ & $\begin{array}{c}0.0321^{* * *} \\
(0.0128)\end{array}$ & $\begin{array}{l}0.0229^{*} \\
(0.0139)\end{array}$ & $\begin{array}{c}0.0227 \\
(0.0138)\end{array}$ & $\begin{array}{l}0.0230^{*} \\
(0.0139)\end{array}$ \\
\hline Customer Rel. Management ( $C R M)$ & $\begin{array}{l}-0.0174 \\
(0.0131)\end{array}$ & $\begin{array}{l}-0.0155 \\
(0.0129)\end{array}$ & $\begin{array}{l}-0.0161 \\
(0.0129)\end{array}$ & $\begin{array}{l}-0.0065 \\
(0.0120)\end{array}$ & $\begin{array}{l}-0.0053 \\
(0.0120)\end{array}$ & $\begin{array}{l}-0.0053 \\
(0.0120)\end{array}$ \\
\hline Export Activity & $\begin{array}{c}0.0162 \\
(0.0127)\end{array}$ & $\begin{array}{c}0.0158 \\
(0.0127)\end{array}$ & $\begin{array}{c}0.0166 \\
(0.0127)\end{array}$ & $\begin{array}{l}0.0278^{*} \\
(0.0153)\end{array}$ & $\begin{array}{l}0.0280^{*} \\
(0.0151)\end{array}$ & $\begin{array}{l}0.0291^{*} \\
(0.0152)\end{array}$ \\
\hline East Germany & $\begin{array}{c}0.0103 \\
(0.0122)\end{array}$ & $\begin{array}{c}0.0102 \\
(0.0122)\end{array}$ & $\begin{array}{c}0.0116 \\
(0.0122)\end{array}$ & $\begin{array}{l}-0.0094 \\
(0.0121)\end{array}$ & $\begin{array}{l}-0.0096 \\
(0.0123)\end{array}$ & $\begin{array}{l}-0.0081 \\
(0.0123)\end{array}$ \\
\hline Constant & $\begin{array}{l}-0.0075 \\
(0.0233)\end{array}$ & $\begin{array}{l}-0.0085 \\
(0.0231)\end{array}$ & $\begin{array}{c}-0.0043 \\
(0.0228)\end{array}$ & $\begin{array}{c}0.1102^{* * *} \\
(0.0319)\end{array}$ & $\begin{array}{c}0.1075^{* * *} \\
(0.0316)\end{array}$ & $\begin{array}{c}0.1122^{* * *} \\
(0.0318)\end{array}$ \\
\hline Number of Observations & 880 & 880 & 880 & 1176 & 1176 & 1176 \\
\hline F-statistic & 4.83 & 4.88 & 4.88 & 10.40 & 10.41 & 10.41 \\
\hline$R^{2}$ & 0.1623 & 0.1614 & 0.1601 & 0.2297 & 0.2302 & 0.2280 \\
\hline
\end{tabular}

